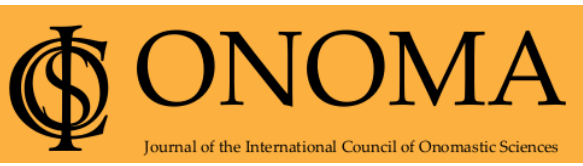

Onoma 56

Journal of the International Council of Onomastic Sciences

ISSN: 0078-463X; e-ISSN: 1783-1644

Journal homepage: https://onomajournal.org/

\title{
H.E. Chehabi, Onomastic reforms, family names and state building in Iran, Boston, Massachusetts: Ilex Foundation, 2020, pp. vii + 109, ISBN: 978067428199
}

\section{Wafa Abu Hatab*}

Zarqa University, Jordan

To cite this article: Abu Hatab, Wafa. 2021. H.E. Chehabi, Onomastic reforms, family names and state building in Iran, Boston, Massachusetts: Ilex Foundation, 2020, pp. vii + 109, ISBN: 978067428199. Onoma 56, 295-298. DOI:

10.34158/ONOMA.56/2021/15

To link to this article: https://doi.org/10.34158/ONOMA.56/2021/15

(C) Onoma and the author.

\section{Article history}

Received on 30 September 2021.

Final form accepted on 11 December 2021.

Published online on 13 December 2021. 


\section{H.E. Chehabi, Onomastic reforms, family names and state building in Iran, Boston, Massachusetts: Ilex Foundation, 2020, pp. vii + 109, ISBN: 978067428199}

WAFA ABU HATAB

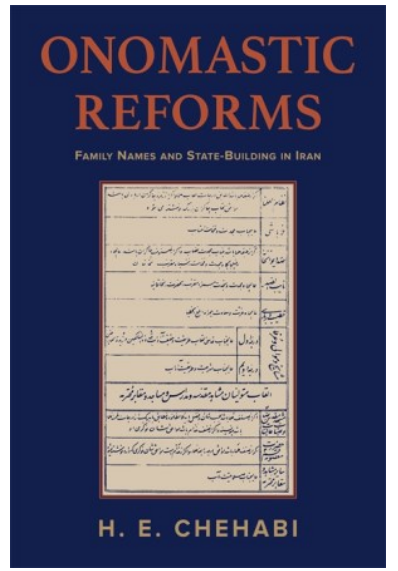

(https://www.hup.harvard.e du/catalog.php?isbn $=978$ 0674248199)
Being written by an author with a strong background in political sciences and international relations, Onomastic reforms (2020) provides a unique account of the traditional naming practices in Iran before and after the reform. While most onomastic research is linguistically oriented, Chehabi's (2020) tackles onomastic reform in Iran from a remarkable socio-political perspective.

The book consists of four chapters tracing the history of the establishment of Iran's new onomastic regime in the second and third decades of the twentieth century outlining the legislative measures and decrees that constituted the reform focusing on naming processes as far as surnames are concerned and the debates involved in the naming practices.

The first chapter introduces the reader to the establishment of the onomastic regime in Iran dealing with the measures that were introduced and the processes involved in the standardization of naming practices providing examples from Iran, France, the Ottoman empire, Japan, Thailand, Ethiopia, and Algeria. The chapter touches on the concept of titles in France and Germany and honorifics in America, Japan, Turkey, and Spain showing how the heredity family names could be viewed as an "act of acculturation practice" (Chehabi 2020: 10). The chapter deals with the challenges of the standard of civilization reviewing the political status of Iran in the 19th century and how it affected the naming practice focusing on the use of family names in Iran and relating it to practices in Europe. The chapter also discusses naming in Iran in the first quarter of the twentieth century explaining how it was influenced by the political atmosphere at that time, Iran's constitutional revolution 19051906, World War I and the reform measures before and after 1921 Coup. The author connects the standardization of naming practices to state-building practices. The final section shows how state-building affected the naming 
practices as far as surnames are concerned concluding that the focus was on establishing a centralized civil registry rather than the adoption of surnames.

Chapter two focuses on the traditional naming practices, components of Iranian names and honorary titles. Chehabi provides five components for traditional Iranian names: a kunya (teknonym), an ism (a proper name), nasab (patronym), nisba (relational adjective), and laqab (title). The influence of these components on creating surnames and the Turkish influences are discussed as well. This chapter surveys the history of honorary titles in Iran tracing them back to the Achaemenian times. Honorary titles were given first to viziers then the Hamdanid rulers of Syria and Buyid rulers of Iraq and western Iran. At a later stage, the brothers Ali, Hasan, and Ahmed were given the honorary titles 'Emad al-Dowleh ('Pillar of the State'), Rokn al-Dowleh ('Column of the State'), and Mo'ezz al-Dowleh ('Fortifier of State'). The chapter provides a description of the roles played by these titles and the way gender influenced them. This chapter also tackles the naming practices in the twentieth century and the Constitutional Revolution effect where new elements were introduced before the name such as Mirza a preceding the names of literate men and Aqa preceding the names of merchants. Women used terms such as Khãnom. Other religion-related terms also appeared such as Mollã and Sheykh. Chehabi also discusses address forms that were used to express politeness and signal social status such as jenãb and khedmat and the term Hojjat al-Eslam ('proof of Islam') assigned for top clerics and Ayat Allãh ('Sign of God') for top Muslim scholars. The chapter ends with citing examples of the way Iranian names were affected by European naming practices

The third chapter is devoted to laws imposed by the State on the naming practices providing an overview of the Law of 1918 and the steps it passed through. Here the State is interfering asking heads of families to choose surnames for themselves and their families. The benefits of this law in the short and long run are also discussed supported with examples of how newspapers reacted to some naming practices in 1919 and other examples of how affiliation was established through the naming practices. Furthermore, an analysis of names notices is provided. This interesting analysis sheds some light on attitudes towards family names and the reasons behind choosing a family name rather than the other. The second section of the chapter surveys naming practices under the laws of 1925-1928 supported with examples of naming laws of solar months in Persian. A move towards discouraging the use of titles was enforced by legal practice that was supported by the Parliament that called for abolishing some titles. Chehabi (2020: 54) considers abolishing titles as a central part of a campaign against the Qãjãr dynasty emphasizing the relation between military concerns and name standardization laws. The section on the 1935 Circular of Honorifics explains how it was motivated by the visit of Reza Shah to Turkey. The 1935 reform aimed at standardization of honorific titles paying special attention to royal titles of the Shah, the Queen and the Crown 
Prince. Honorifics attached to cities, ministries, and state administration were abolished. Another article abolished honorifics that precede names such as 'maqam-e mani' ('impregnable Rank'). Other articles tackled address terms of foreign delegates in an attempt to harmonize Iranian names internationally. The chapter tackles later modifications concerning forenames and surnames, the type and effect of forbidden names, the relation between family names and place of birth, and processes involved in adopting surnames. The year 1985 is marked by elaboration on criteria of judging whether the name is "insulting to Islam". Other ordinances for 2009 and 2012 considering names are also discussed.

The final chapter is devoted to the post-1925 naming practices. The first section deals with the actual names taken by the Iranians while the social consequences of the new onomastic regime are dealt with in the second section. The chapter closes by placing the Iranian experience within the international context. The first section discusses the factors that determine the choice of a certain surname such as religion, residence, marriage, and the desire to be connected to one's ancestors. The basis upon which Iranians invented their surnames is also discussed explaining how surnames were generated and affected by the honorary titles. Nisbas sources and functions are also discussed with examples. The chapter also touches on non-Muslim names giving some examples for Jewish surnames and the Baha'is and the influence of demographic factors on the naming practices in rural areas.

The section entitled "Family Names in the Social Context" tackles the social factors that affected the naming practice such as taking advantage of some peasants' ignorance, the resistance towards revealing women's names, the role of religion, fatwas and the influence of the educational system. Other social factors involved the social effect of abolition titles, introducing family names and identity cards, the fall of the Shah, the Constitutional Revolution, military titles, social classes and challenges imposed by migration. 